\title{
The Pattern of Temporary International Migration in Sri Lanka
}

\author{
Lakshman Dissanayake $^{1 *}$ and Irangi Samarakoon ${ }^{2}$ \\ ${ }^{1}$ Emeritus Professor of Demography, Faculty of Arts, University of Colombo \\ ${ }^{2}$ Lecturer, Department of Demography, Faculty of Arts, \\ University of Colombo \\ *Corresponding author: Lakshman Dissanayake, Email: 1.dissanayake@ demo.cmb.ac.lk
}

\begin{abstract}
This study differs from earlier studies by using terminology which defines temporary international migration as those who were abroad more than six months at the time of the investigation for purpose other than permanent residence. This includes not only the labour migrants but also other categories such as those who have gone for educational purposes. One of the most noticeable features is the dominance of estate sector women compared to other sectors because a higher percentage of estate women has gone abroad temporarily compared to women in urban and rural sectors. The study also suggests that one of the push factors for temporary international migration seeking employment as the differences in poverty levels in urban, rural and estate sectors. Furthermore, it was found that more younger women in the estate sector who are in the labour force ages move abroad for employment. It was revealed from the analysis that the districts which show a higher level of migration for employment, also exhibit a higher level of migration for education compared to less mobility districts. This means that there is a clear distinction between migrant districts and non-migrant districts irrespective of reasons for migration. Districts in the North-east Sri Lanka seem to be less mobile both locally and internationally. This can be due to the disruption that occurred in those districts as a result of 30-year long civil war which was concluded in 2009. However, one can predict that they also will follow a general pattern of international migration. It was observed that the majority moved to Middle East Countries for employment and a significant number were travelling to OECD countries for higher education.
\end{abstract}

Keywords: International Migration, Estate Sector, Employment, Higher Education, Women 


\title{
Introduction
}

Migration is considered as one of the major components of population change at the country level when international migratory movements are being studied. International migration can either be permanent or temporary depending on the reasons for such migrations. In the case of permanent migration, countries lose people with emigration and regain with immigration. The positive or negative sign of net migration decides whether a country is losing from or adding to the existing population at a given time point or period. However, it is quite important to understand, in the contemporary world, that it is not only permanent migration taking place but also temporary migration is visible at relatively high magnitude. Most of the time, when international migration is examined, undue attention has been given to permanent migration but by pooling temporary migration into it. This may be mainly because of the definition of a migrant as International Organization of Migration (IOM)

\begin{abstract}
"defines a migrant as any person who is moving or has moved across an international border or within a State away from his/her habitual place of residence, regardless of (1) the person's legal status; (2) whether the movement is voluntary or involuntary; (3) what the causes for the movement are; or (4) what the length of the stay is" ${ }^{1}$.
\end{abstract}

In this definition, length of stay is a matter of concern because the impact of permanent migration and temporary migration on the country of origin and destination differs considerably. Therefore, the present study is focused upon the temporary migration for those who have gone abroad for a duration of more than 6 months other than for a permanent residence. They can be regarded as temporary migrants because they do not have any intention to reside at the destination country permanently and thus they will return to their country of origin once they have completed their tasks. This means that these temporary migrants move to a destination country for a specific purpose such as obtaining education or engaging in employment activity for a certain duration of time. However, such temporary migration has been always linked to labour migration ${ }^{2}$.

\footnotetext{
${ }^{1}$ https://www.un.org/en/sections/issues-depth/migration/index.html

${ }^{2} \mathrm{http}$ ://www.oecd.org/migration/international-migration-outlook-france-september2019.htm
} 
Migration decisions are very much related to gender and age of people. Furthermore, migration experiences of girls and women in certain age groups show that they are more or less likely to experience sexual and gender-based violence, or labour exploitation and human trafficking (Birchall, 2016). Gender aspect of migration can help to provide guidance to prepare strategies for managing migration. This aspect has not been looked at separately in most of the migration studies conducted in Sri Lanka or elsewhere and hence, this study examines the sex differentials of temporary international migration in Sri Lanka by examining various socio-economic characteristics of the migrants.

\section{Data}

Data for this study is mainly obtained from the Population and Housing Census of Sri Lanka conducted in 2012. Population Census of 2012 was conducted on $20^{\text {th }}$ March 2012 by adopting the de jure method using the usual residence concept ${ }^{3}$. 'Population gone abroad temporarily' is a new question included in the census of 2012 for the first time in Sri Lanka. In this case, temporary migrants are the household members who have gone abroad for a duration of more than 6 months other than for a permanent residence. The total number of census block identified for the census was 65,012 .

\section{Results and Discussion}

Analysis of census data revealed that population size in urban, rural and estate sector does not have any relationship with a number of migrants generated by these sectors. The ratio of temporary migrants in each sector to the total number of population in the respective sector shows that urban sector has 3.7 percent migrants whereas rural and estate sector have 2.6 and 2.7 percent, respectively although the proportion of the population in each sector is 18.2 , 77.4 and 4.4 percent separately for urban, rural and estate sector, respectively. One of the most noticeable features is the dominance of the estate sector women compared to other sectors. It is found that 3.8 percent of estate women have gone abroad temporarily compared to about 2 percent women in the other two sectors. Among men, the estate sector showed the lowest percentage and urban sector recorded the highest percentage (5.2\%) of migrant men.

\footnotetext{
${ }^{3}$ http://www.statistics.gov.lk/PopHouSat/CPH2011/Pages/Activities/Reports/CPH_2012_ 5Per_Rpt.pdf
} 
In this case, it would be very much interesting to examine the reasons for such international moves by men and women in these sectors, separately. It was found that employment was the main reason for moving abroad by all the sector and the highest percentage in the estate sector followed by the rural sector for both sexes as shown in Table1. However, a higher percentage of women from the estate sector has sought employment abroad compared to their male counterparts. The urban sector shows the lowest international migration with 80.4 percent of men and 64.3 percent of women moving to overseas for employment

Table 1: Percentage distribution of reasons for temporary international migration by sex and sector, Sri Lanka

\begin{tabular}{|l|l|l|l|}
\hline \multirow{2}{*}{ Reasons } & \multicolumn{2}{l}{ Sector } & \multicolumn{2}{l|}{} \\
\cline { 2 - 4 } & Urban & Estate \\
\hline Male & \multicolumn{2}{|l|}{} \\
\hline Employment & 80.4 & 90.8 & 97.7 \\
\hline Education & 13.9 & 5.6 & 1.1 \\
\hline Other & 5.6 & 3.6 & 1.2 \\
\hline Total & 100 & 100 & 100 \\
\hline Female & \multicolumn{3}{|l}{} \\
\hline Employment & 64.3 & 89.2 & 99.3 \\
\hline Education & 16.2 & 4.1 & 0.3 \\
\hline Other & 19.5 & 6.7 & 0.4 \\
\hline Total & 100 & 100 & 100 \\
\hline
\end{tabular}

Source: Authors' calculation from the Census of Population 2012

When chi-square test is performed to find whether there is a clear association between reasons for employment and sectors by controlling for sex, it is found that there is a significant association between the two variables as all the chisquare value is highly significant (Table 2). This suggests that the place of residence is influential in making the decision to migrate abroad temporarily, mainly for employment. 
Table 2: Chi-Square Test: Reasons for going abroad for employment and sector

Chi-Square Tests

\begin{tabular}{|l|l|l|l|}
\hline & Value & df & $\begin{array}{l}\text { Asymptotic Significance } \\
(2-\text {-sided })\end{array}$ \\
\hline Pearson Chi-Square & $24495.067^{\mathrm{a}}$ & 4 & .000 \\
\hline Likelihood Ratio & 23450.905 & 4 & .000 \\
\hline $\begin{array}{l}\text { Linear-by-Linear } \\
\text { Association }\end{array}$ & 18056.876 & 1 & .000 \\
\hline N of Valid Cases & 573204 & & \\
\hline
\end{tabular}

Source: Authors' calculation from the Census of Population 2012

One of the push factors for temporary international migration seeking employment can be the differences in poverty levels in these sectors. According to the Poverty Head Count Index calculated from the Household Income and Expenditure Survey of 2012, shows that estate sector records 10.9 percent while urban and rural sectors reveal 2.1 and 7.6 percent for those two sectors, respectively. This is further visible from Table 3 when income levels of these three sectors are compared. It is quite discernible that the estate sector income is considerably lower than the urban and rural sectors.

Table 3: Median monthly gross salary by sector, 2019

\begin{tabular}{|l|l|l|l|l|l|l|}
\hline & \multicolumn{2}{|l|}{$\begin{array}{l}\text { Monthly } \\
\text { (wage/salary) } \\
\text { Rs. }\end{array}$} & earners & \multicolumn{2}{l|}{$\begin{array}{l}\text { Daily earners (wage/salary) } \\
\text { Rs. }\end{array}$} \\
\hline & urban & rural & estate & urban & rural & estate \\
\hline $\begin{array}{l}\text { Median } \\
\text { Income }\end{array}$ & 36,000 & 34,000 & 18,500 & 25,000 & 22,500 & 16,650 \\
\hline
\end{tabular}

Source: Authors' calculation from the Census of Population 2012

The Age pattern of temporary international migration in each sector is depicted in Figure 1. It reveals that the age pattern is similar in all the sectors with domination in the labour force ages. However, the level is higher in the estate sector with the smaller spread of the age curve compared to the other two sectors. It is also observed that mean age of the women in the estate sector (32.75 years) is about two years younger to women in the urban (34.38) and rural (34.58) sectors of those who have gone abroad for employment. 


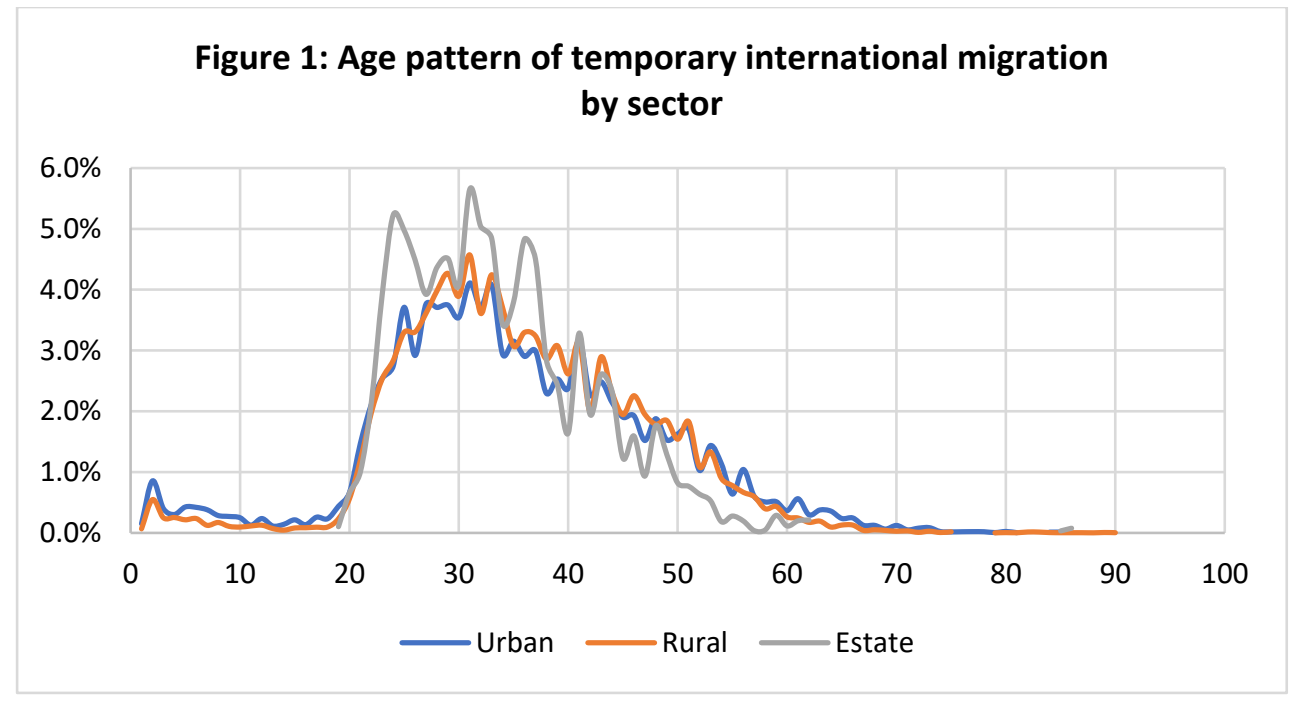

Source: Authors' calculation from the Census of Population 2012

Figure 2 shows that Colombo and Gampaha districts dominate the temporary international migration while Kandy from the central hills and Kurunegala and Puttalam districts from the North-central province also demonstrate a significant proportion of migrants. One of the most noticeable features is except Jaffna, Batticaloa and Ampara, all other districts in the Northern and Eastern provinces exhibit a very marginal proportion of migrants.

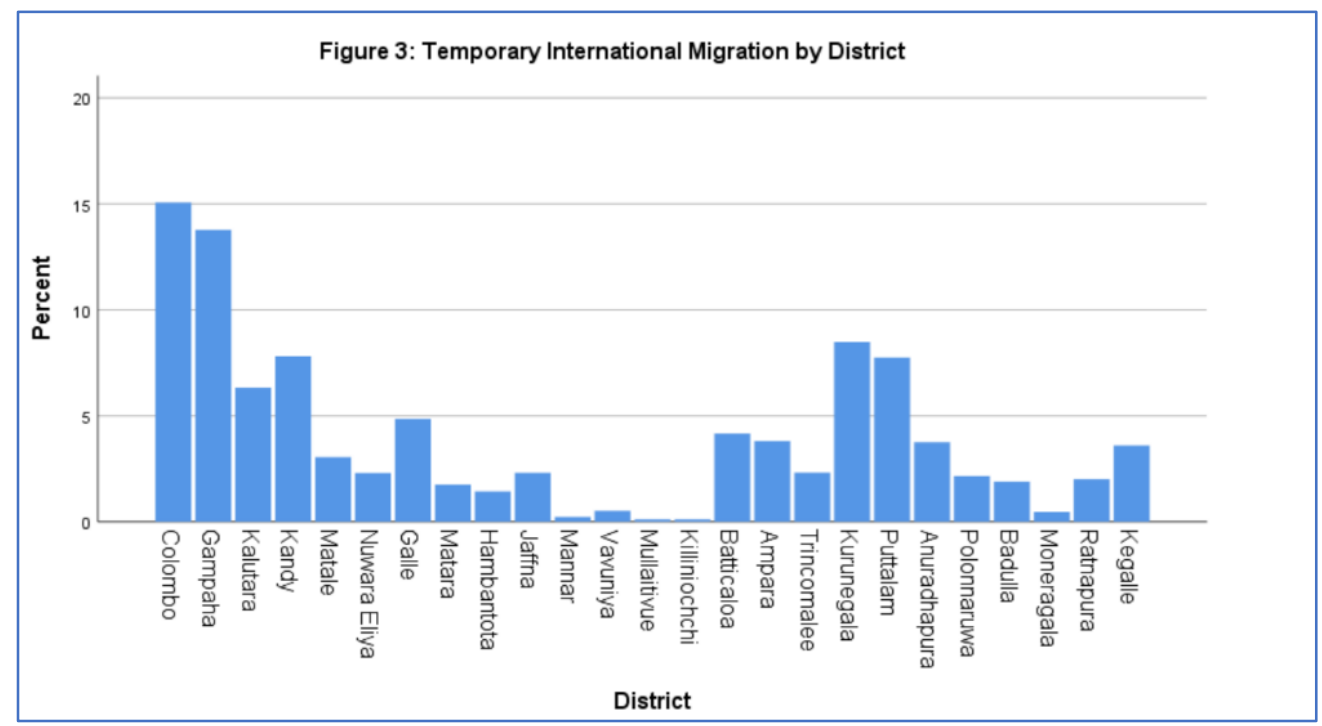

Source: Authors' calculation from the Census of Population 2012 
Although Colombo district showed the highest percentage of migrants, a significant proportion of them has migrated for education and other reasons. However, Kurunegala and Puttalam districts show that temporary international migration was mainly due to seeking employment abroad and other factors have very less significance. Colombo, Gampaha and Kandy districts are more urban in character whereas Kurunegala and Puttalam are more rural. When the employment status of the labour force in these districts are considered, 48.5 and 46.2 percent of employed persons are self-employed in Kurunegala and Puttalam districts, respectively. This means a majority of the workers are either own account workers or contributing family workers. In Colombo, Gampaha and Kandy districts, these percentages are 32.1, 33.6 and 38.1, respectively. This suggests that volatility in income generation activities of the informal sector engagements in the northwestern province has operated as one of the push factors of temporary international labour migration.

Table 4: Percentage distribution of reasons for migration by districts with high proportion of migrants

\begin{tabular}{|l|l|l|l|l|l|}
\hline \multirow{2}{*}{ Reasons } & \multicolumn{5}{|l|}{ District } \\
\cline { 2 - 6 } & Colombo & Gampaha & Kandy & Kurunegala & Puttalam \\
\hline Employment & $71.3 \%$ & $82.0 \%$ & $87.5 \%$ & $93.2 \%$ & $91.7 \%$ \\
\hline Education & $17.5 \%$ & $9.9 \%$ & $6.8 \%$ & $4.1 \%$ & $3.3 \%$ \\
\hline Other & $11.2 \%$ & $8.1 \%$ & $5.7 \%$ & $2.7 \%$ & $5.0 \%$ \\
\hline & $100.0 \%$ & $100.0 \%$ & $100.0 \%$ & $100.0 \%$ & $100.0 \%$ \\
\hline
\end{tabular}

Source: Authors' calculation from the Census of Population 2012

Another important feature observed in the analysis of temporary migration by the district is the high level of mobility in the district will have a greater impact on people to migrate overseas for various other reasons. In other words, there is a close association between the reasons for migration among themselves and district of residence as depicted in Figure 4 as well as the Chi-square test performed in this analysis (Table 5). It is quite clear from Figure 4 that the districts which show a higher level of migration for employment, also exhibit a higher level of migration for education compared to less mobility districts. 
Figure 4: Temproarily emigrating for employment and education by districts, Sri Lanka

40.0

35.0

30.0

25.0

20.0

15.0

10.0

5.0

0.0

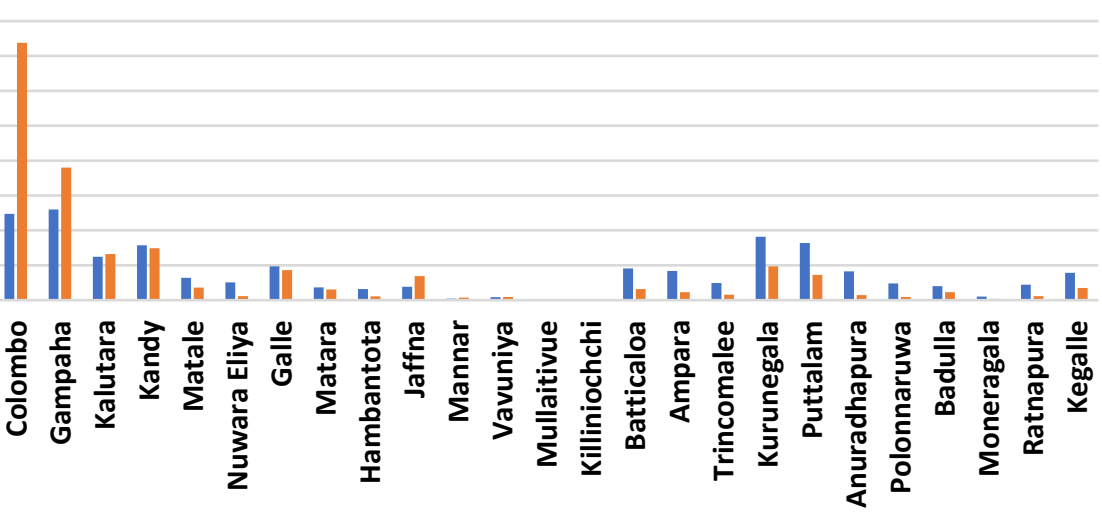

Migrated overseas for Employment Migrated overseas for Education

Source: Authors' calculation from the Census of Population 2012

When Chi-Square test is performed in order to find out whether there is any association between reasons for international migration and district of residence, test results in Table 5 show that there a significant association between those two variables. This suggests that those who tend to migrate for various reasons come from the same districts.

Table 5: Chi-Square Test for reasons for migration abroad and the district of residence

\begin{tabular}{|l|l|l|l|}
\hline \multicolumn{2}{|l|}{ Chi-Square Tests } & & $\begin{array}{l}\text { Asymptotic } \\
\text { Significance } \\
\text { (2-sided) }\end{array}$ \\
\hline & Value & df & .000 \\
\hline Pearson Chi-Square & $39184.625^{\mathrm{a}}$ & 48 & .000 \\
\hline Likelihood Ratio & 37307.780 & 48 & .000 \\
\hline $\begin{array}{l}\text { Linear-by-Linear } \\
\text { Association }\end{array}$ & 15150.495 & 1 & \\
\hline N of Valid Cases & 573206 & & \\
\hline
\end{tabular}

Source: Authors' calculation from the Census of Population 2012 
It is quite interesting to note that districts of origin for employment and education are almost similar for internal and international migrants. Similarity exists in both magnitudes of mobility and the pattern of migration as depicted in Figure 5. This can be due to the highly urbanized nature of Colombo and Gampaha districts which opens up the opportunity for international migration. Additionally, migration industry developed in the country for last few decades is in full operation in these two districts and hence those who intend to migrate overseas for employment or education, have the change of getting information as well as the necessary assistance more than in any other districts. As mentioned earlier, the nature of informal employment opportunities available in Kurunegala and Puttalam has forced people to be more mobile internally as well as internationally.

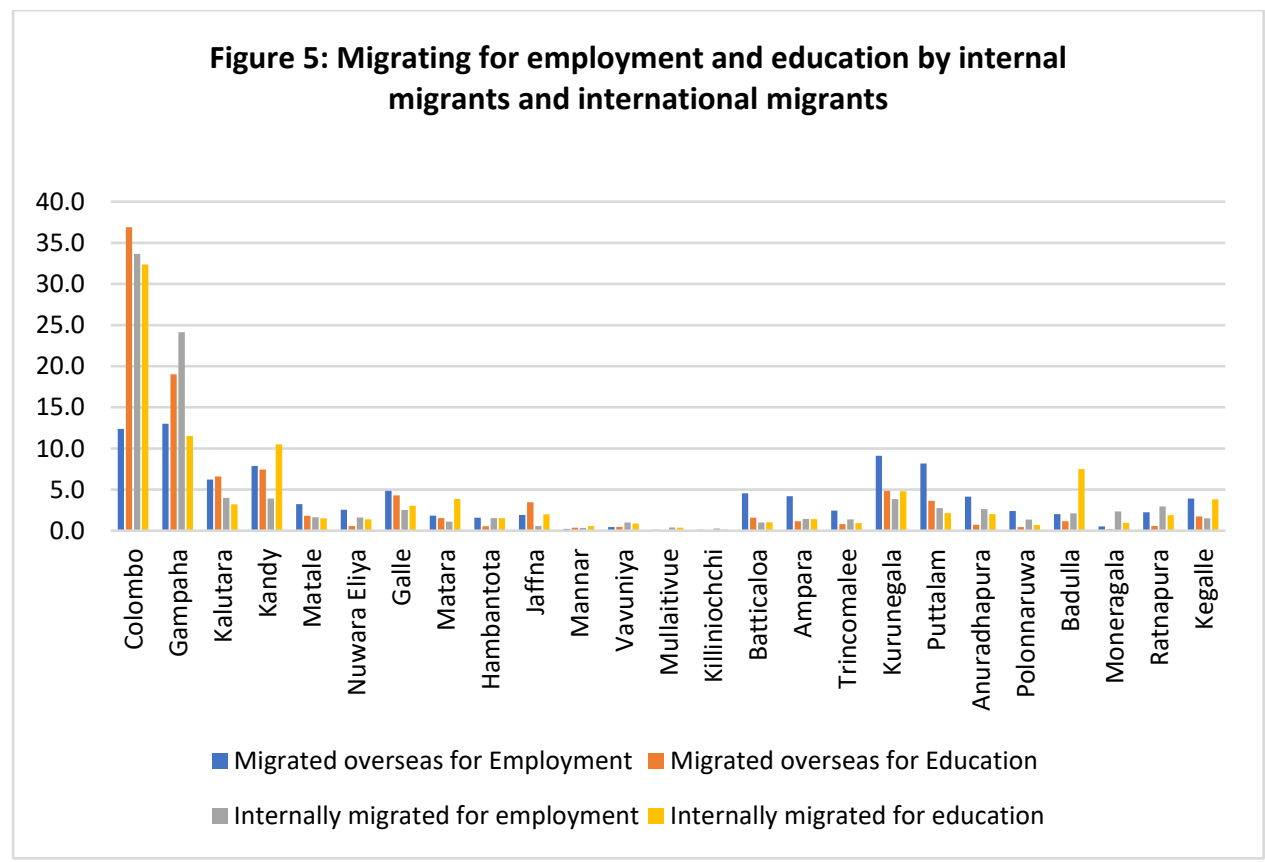

Source: Authors' calculation from the Census of Population 2012

Analysis done so far at district level reveals that district in North-east Sri Lanka seems to be less mobile both locally and internationally. This can be due to the disruption that occurred in those districts as a result of 30-year long civil war which was concluded in 2009. The war displaced a significant number of people in these districts and a resettlement process began after 2009. The resettlement process itself has delayed their move overseas or any other district within the country because they needed to move first to the places where they were residing before or during the war. Once they are fully 
resettled, one can predict that they also will follow a general pattern of international migration. It is also important to note that majority of irregular migrants originated from these districts mainly because of economic reasons as well as protection issues (Hugo and Dissanayake, 2017).

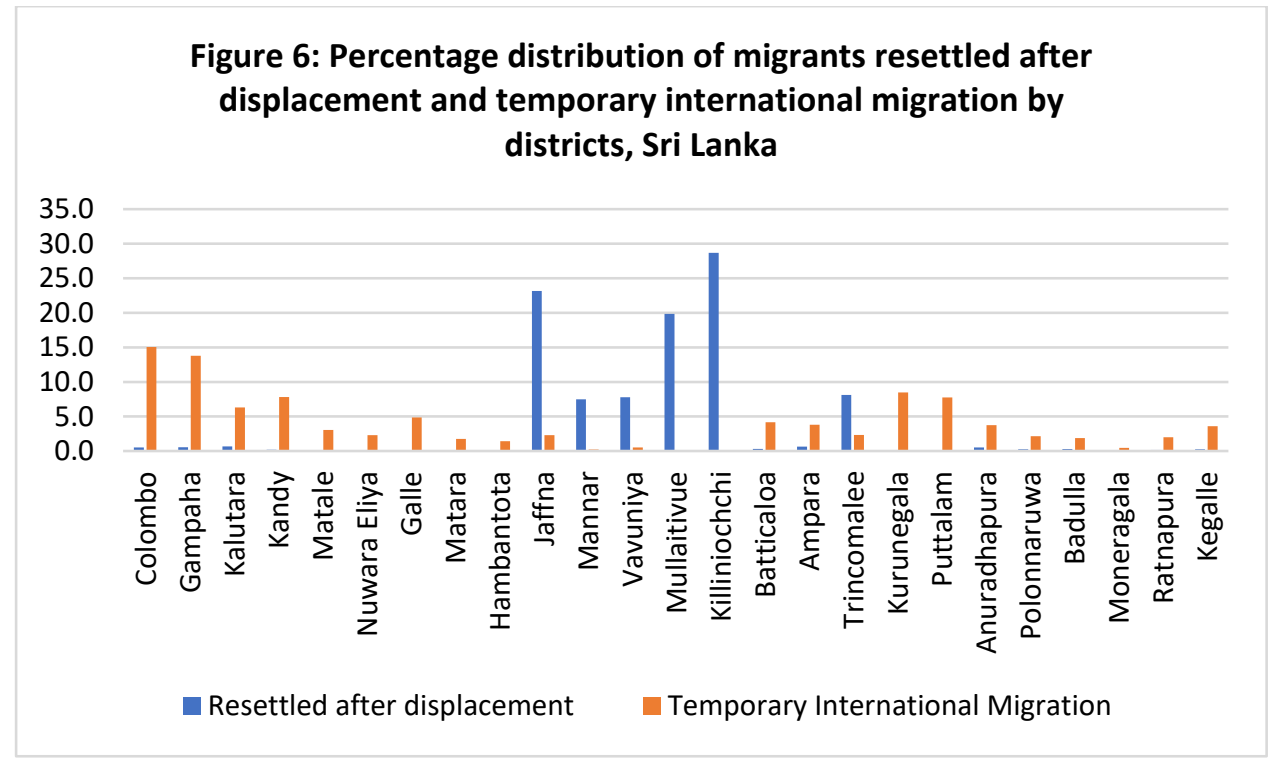

Source: Authors' calculation from the Census of Population 2012

When country of destination related to the reason for going overseas is examined, it is found that majority moved to Middle East Countries and if it is education, migrants were travelling to OECD countries (Table 6).

Table 6: Country of destination by reason for migration abroad, Sri Lanka

\begin{tabular}{|c|c|c|c|c|c|c|c|}
\hline & \multicolumn{5}{|c|}{ country } & \multirow[b]{2}{*}{ Total } \\
\hline & & $\begin{array}{l}\text { South } \\
\text { Asia }\end{array}$ & $\begin{array}{l}\text { East } \\
\text { Asia }\end{array}$ & $\begin{array}{l}\text { Middle } \\
\text { East }\end{array}$ & OECD & Other & \\
\hline \multirow[t]{3}{*}{ REASON } & Employment & $1.8 \%$ & $6.1 \%$ & $76.0 \%$ & $13.7 \%$ & $2.4 \%$ & $100.0 \%$ \\
\hline & Education & $6.8 \%$ & $9.2 \%$ & $19.6 \%$ & $59.3 \%$ & $5.1 \%$ & $100.0 \%$ \\
\hline & Other & $5.9 \%$ & $5.5 \%$ & $42.8 \%$ & $42.0 \%$ & $3.9 \%$ & $100.0 \%$ \\
\hline \multicolumn{2}{|l|}{ Total } & $2.4 \%$ & $6.3 \%$ & $70.0 \%$ & $18.6 \%$ & $2.7 \%$ & $100.0 \%$ \\
\hline
\end{tabular}

Source: Authors' calculation from the Census of Population 2012 
When this phenomenon is further investigated to find whether the relationship between reasons for emigrating overseas and country of destination is statistically significant, it was found that there is a strong association between the two variables as shown in Table 7 with Chi-square test of significance.

Table 7: Chi-square test: Reasons for emigrating to overseas and country of destination

\section{Chi-Square Tests}

\begin{tabular}{|l|l|l|l|}
\hline & Value & df & $\begin{array}{l}\text { Asymptotic Significance } \\
\text { (2-sided) }\end{array}$ \\
\hline Pearson Chi-Square & $81665.404^{\mathrm{a}}$ & 8 & .000 \\
\hline Likelihood Ratio & 70945.795 & 8 & .000 \\
\hline $\begin{array}{l}\text { Linear-by-Linear } \\
\text { Association }\end{array}$ & 10855.676 & 1 & .000 \\
\hline N of Valid Cases & 573205 & & \\
\hline
\end{tabular}

Source: Authors' calculation from the Census of Population 2012

It is also important to find whether these temporary migrants have preferred certain countries of destinations. Further analysis in this line showed that the majority have moved to the Middle East but there was significant mobility towards the Maldives in the Asian region and South Korea in the East Asian region for employment purposes. There are about 15000 to 20000 Sri Lankans are employed in the Maldives ${ }^{4}$. There are about 22,000 migrant workers in South Korea engaged in low-skilled jobs ${ }^{5}$. This is mainly because of employment opportunities available in the Maldives and annual job quota provided by the South Korean government for Sri Lankans. For education, it was mainly Australia and New Zealand were two major countries of destination.

\footnotetext{
${ }^{4} \mathrm{https}$ ://mfa.gov.lk/sri-lankan-workers-in-maldives-could-benefit-from-the-countrys-borderreopening-maldivian-high-commissioner-informs-prime-minister-rajapaksa/

${ }^{5}$ https://www.pressreader.com/sri-lanka/daily-mirror-sri-lanka/20191218/281986084450953
} 


\section{Conclusion}

The present study defined temporary international migration as those who were abroad more than six months at the time of the investigation for a purpose other than permanent residence, which is quite different from earlier studies done on international migration. Therefore, the study included not only the labour migrants but also other types of migrants, namely those who have gone for educational purposes. One of the most visible characteristics is the dominance of estate sector women contrasted to other sectors because a greater percentage of estate women has gone abroad temporarily compared to women in urban and rural sectors. It was found that employment was the main reason for moving abroad by all the sectors and the highest percentage in the estate sector followed by the rural sector for both sexes. Statistical analysis performed in this study further proved that the place of residence is influential in deciding to migrate abroad temporarily, especially for employment purpose. The study also suggests that one of the push factors for temporary international migration seeking employment as the differences in poverty levels in urban, rural and estate sectors. Furthermore, it was found that more younger women in the estate sector who are in the labour force ages move abroad for employment. Colombo and Gampaha districts dominate the temporary international migration while Kandy from the central hills and Kurunegala and Puttalam districts from the north-central province also demonstrate a significant proportion of migrants. Colombo, Gampaha and Kandy districts are more urban in character whereas Kurunegala and Puttalam are more rural. The study suggests that volatility in income generation activities of the informal sector engagements in the northwestern province has operated as one of the push factors of temporary international labour migration. It was revealed from the analysis that the districts which show a higher level of migration for employment, also exhibit a higher level of migration for education compared to less mobility districts. This means that there is a clear distinction between migrant districts and non-migrant districts irrespective of reasons for migration. It was found that the districts of origin for employment and education are almost similar for internal and international migrants. This can be due to highly urbanized nature as well as the nature of informal employment opportunities available which forced people to be more mobile internally as well as internationally. Districts in North-east Sri Lanka seem to be less mobile both locally and internationally. This can be due to the disruption that occurred in those districts as a result of 30-year long civil war which was 
concluded in 2009. However, one can predict that they also will follow a general pattern of international migration. It was observed that the majority moved to Middle East Countries for employment and a significant number were travelling to OECD countries for higher education. Other than the Middle East, two other preferable destinations for employment were Maldives and South Korea while Australia and New Zealand were the most desirable destination for higher education.

\section{References}

Birchall, J. (2016) Gender, Age and Migration, Institute of Development Studies, UK Department of International Development.

Hugo, G.J.; Dissanayake, L. (2017) The process of Sri Lankan migration to Australia focusing on irregular migrants seeking asylum, (ed. McAuliffe, M \& Koser, K ) A long way to go: Irregular migration patterns, processes, drivers and decision making, ANU Press, Canberra.

http://www.oecd.org/migration/international-migration-outlook-france-september2019.htm

http://www.statistics.gov.lk/PopHouSat/CPH2011/Pages/Activities/Reports/CPH_2 012_5Per_Rpt.pdf

https://mfa.gov.lk/sri-lankan-workers-in-maldives-could-benefit-from-the-countrysborder-reopening-maldivian-high-commissioner-informs-prime-minister-rajapaksa/

https://www.pressreader.com/sri-lanka/daily-mirror-sri-

lanka/20191218/281986084450953

https://www.un.org/en/sections/issues-depth/migration/index.html 
